\title{
Ethical Leadership and Moral Efficacy: Ethical Climate as a Mediator
}

\author{
Dafeng Peng, Junlong Zhang and Qing Tian* \\ Macao University of Science and Technology, Macao, China \\ *Corresponding author
}

\begin{abstract}
In a survey with $73.56 \%$ response rate of 662 employees in 21 work units among 9 industries, across multiple organizations, by using questionnaire with convenience sampling and stratified sampling to get sample data, the relationship among ethical leadership, ethical climate and moral efficacy were examined. Using SPSS 21.0 to conduct a data analysis, we found support for our hypothesized models that (1) ethical leadership will have positive impact on moral efficacy (2) ethical leadership will be positively related to ethical climate (3) ethical climate will mediate the relationship between ethical leadership and moral efficacy. In the later, theoretical and practical implications of these findings and limitation, as well as suggestions for future avenues for researches and practice will be discussed.
\end{abstract}

Keywords-ethical leadership; ethical climate; moral efficacy

\section{INTRODUCTION}

Many previous researches to understanding the ethical context of organizations often relate to employee's ethical behaviors (Schminke, Ambrose, \& Neubaum, 2005; Mayer, Kuenzi \& Greenbaum, 2009; Lu, Kuo \& Chiu, 2013) [18] [16] [13], they overlook another component of ethical context, moral efficacy, also plays an important role in ethical context. Employee's moral potency appears to be very vital that it determine one's mind, intension, belief, courage, efficacy that can helpful in dealing with ethical issue. Especially for moral efficacy, it is contributive for an individual to decide whether he/she will exercise an ethical behavior whiling confronting ethical dilemma and is largely depending on one's belief in his ability to achieve successfully in ethical issue. This research extends ethical context by considering ethical leadership and ethical climate to investigate what the relationships will be among above variables.

\section{THEORETICAL HYPOTHESIS}

According to Brown, Treviño and Harrison (2005), ethical leadership means the demonstration of normatively appropriate conduct through personal actions and interpersonal relationships, and the promotion of such conduct to followers through two-way communication, reinforcement, and decision-making [8]. Prior studies linked ethical leadership to employee's voice behavior (Walumbwa \& Schaubroeck, 2009) [22], employee's misconduct (Mayer et al., 2010) [15], ethical behavior ( $\mathrm{Lu}$ et al., 2013)[13] etc. so as to provide solutions to ethical problems as well as carry out other ideas that help working unit functioning. According to Sean T. Hannah's (2010)[11], moral efficacy was considered as one's belief (confidence) in his or her capabilities to organize and mobilize the motivation, cognitive resources, means, and courses of action needed to attain moral performance, within a given moral domain, while confronting moral adversity. Individual's specific actions should have consistence with his/her mind, intension, efficacy and confidence, and many evidences had shown evidences on the significant relationship between ethical leadership and individuals' external behavior. In this way, ethical leadership may also be an antecedent to one's psychological resources that provide his/her conation for ethical action, especially for one's belief (confidence) in exercising an ethical action and such kind of efficacy can be considerate as moral efficacy. Bandura (1991, 1997) [4][5]demonstrated that social factors like leadership would strengthen efficacy beliefs (confidences), and it had been proved to be positively related to employee's confidence, like perceptions of self-efficacy (Walumbwa, Peterson, Avolio, \& Hartnell ,2010)[23]. Thus, we hypothesize that,

Hypothesis 1: Ethical leadership will have a positive impact on moral efficacy.

Ethical climate can be the shared perceptions employees hold regarding the policies, practices, and procedures that an organization rewards, supports, and expects with regard to ethics (Schminke et al., 2005)[18]. Research demonstrated that leaders can be regarded as interpretive filters of organizational policies and processes for collective members (Kozlowski \& Doherty, 1989) [12]. Victor and Cullen (1988) demonstrated that ethical climate was the prevailing perceptions of typical organizational practices and procedures that have ethical content [21]. In this view, organization can spread the ethical working climate through working practices and procedure. Also, Schneider and Snyder (1975) proposed that ethical climate indicated psychologically meaningful, stable, shared perceptions employees had concerning ethical procedures and policies existing in their employing organizations [19]. Extant research has shown the important role of leaders that are critical in creating an ethical climate (Dickson, Smith, Grojean \& Ehrhart, 2001; Mayer, Kuenzi, Greenbaum, Bardes \& Salvador, 2009) [9] [15]. Leaders set a series of ethical standards in an organization by the ways of carry out practices, policies, and procedures that can be helpful to stimulate employee's perceptions of ethical climate in an organization (Mayer et al. 2009) [15]. Schminke et al. (2005) examined the positive relationship between a leader's moral development and ethical climate in organizations [17]. All of them hold the same views that leaders have substantial power to create and 
maintain ethical standard and processes, and to create a particular kind of ethical climate, which is follow leader' aspiration (Schminke et al. 2005) [17]. Thus, we hypothesize that,

Hypothesis 2: Ethical leadership will be positively related to ethical climate.

A lot of research demonstrated that ethical leaders embody many positive personal characteristics and also seek to influence their employees' morale and work enthusiasm by actively managing ethical conduct. A lot of previous study had examined the significant relationship between a leader's moral development and ethical climate in a great number of organizations (Schminke et al., 2005) [17]. Regarding with moral efficacy, research shown that self-efficacy can generalize and change over time, and a form of efficacy (e.g., moral) can be generalized in a continually broadening set of environmental contexts (Bandura, 1997) [5]. Moreover, based on the various types of experiences and behaviors individuals encountered in their organizations (Ahlheim \& Schneider, 2000)[1], work climates provide valuable guidance to employee decision making about what constitutes or organization appropriate and desired behavior (Victor and Cullen 1988, Gaertner 1991) [21][10]. It can be seemed that moral efficacy can be a kind of employee outcome as employee's confidence that would change under the influence of ethical working climate. We expect that ethical climate is one of the processes through which ethical leadership is related to employee's moral efficacy. Thus, we hypothesize that,

Hypothesis 3: The positively relationship between ethical leadership and moral efficacy will be mediated by ethical climate.

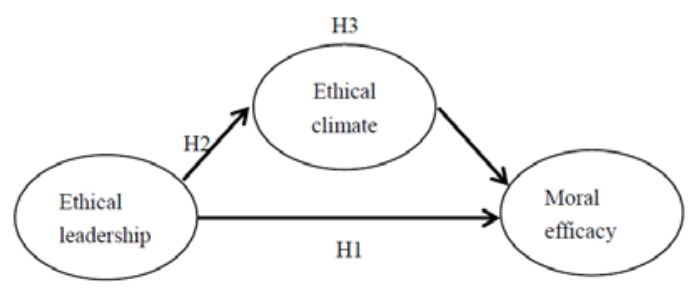

FIGURE I. RESEARCH MODEL

\section{METHODOLOGY}

From Nov. 2014 to Jan. 2015, we distributed 450 questionnaires in Guangdong Province (Zhaoqing \& Zhuhai) and 331 useful questionnaires were received (73.56\%). We adopted both convenience sampling and stratified sampling (the scale rate is approximately $30 \%$ ) to distribute the questionnaires. Moreover, to avoid common method bias, we adopt two times to collect our questionnaires. We firstly distributed ethical leadership and perceived ethical climate questionnaires. Two weeks later, the moral efficacy questionnaire was distributed. The major demographic statistics showed as follow. $57.1 \%$ of the respondents were male, while $42.9 \%$ were female. Most participants were between 18 and 30 year (48.9\%). Most of them got a degree on education of junior college, among which bachelor degree and junior degree took $43.5 \%$ and $31.1 \%$ respectively. $63.4 \%$ of the respondents had less than 5 years working experiences in the current organization.

\section{MEASURES}

Though the questionnaires were in Chinese, the item scales were originally written in English. For the sake of accurate translation, we used conventional method of back translation (Brislin, 1980) [7] to translate the item scales into Chinese and then back into English. All items were measured on a scale ranging from 1 'strongly agree' to 5 'strongly disagree' by Likert-five-point Scale. Regarding Ethical leadership, this study used the 10-item Ethical Leadership Scale (ELS) developed by Brown et al. (2005) [8]. Sample item are "Is open to criticism and different opinion" The Cronbach's alpha for this scale was 0.89 . Regarding ethical climate, this study used a 5-item scale developed by Anke Arnaud and Marshall Schminke(2005) [3]. Sample items like, "In my department it is expected that you will always do what is right for society", The Cronbach's alpha for this scale was 0.80. Regarding moral efficacy, this study used 5-point Moral Efficacy Scale developed by Sean T. Hannah (2010) [11] Items were as following, including "confront others who behave unethically to resolve the issue", The Cronbach's alpha was 0.82 .

TABLE I. MEAN, STANDARD DEVIATIONS, PEARSON CORRELATION COEFFICIENT

\begin{tabular}{llllrrrrrr}
\hline variable & Mean & S.D. & $\alpha$ & 1 & 2 & 3 & 4 & 5 & 6 \\
\hline 1.age & 1.76 & .89 & -- & 1.00 & & & & & \\
2.gender & .43 & .50 & -- & $-.12^{*}$ & 1.00 & & & & \\
3.tenure & 2.42 & 1.42 & - & $-.15^{* *}$ & $.68^{* *}$ & 1.00 & & & \\
4.EL & 3.46 & 0.81 & 0.86 & -.07 & -.11 & -.08 & 1.00 & & \\
5.EC & 3.29 & 0.64 & 0.80 & -.02 & .04 & .04 & $.29^{* *}$ & 1.00 & \\
6.ME & 3.20 & 0.67 & 0.82 & -.09 & -.05 & -0.05 & $.13^{*}$ & $.13^{* *}$ & 1.00 \\
\hline
\end{tabular}

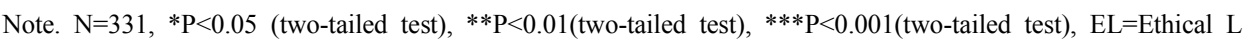
eadership, EC=Ethical Climate, ME=Moral Efficacy

The statistical result would be as bellow. From Table I, it can be seen that the coefficient among the variables were below 0.7 , which means relevance degree of variables was in the reasonable range. As Table 4 showed, correlation 
coefficient between ethical leadership is $0.294 * *$, which support the positive relationship between them. And correlation coefficient between ethical climate and moral efficacy is $0.126^{* *}$.

Table II shows that ethical climate mediate the relationship between ethical leadership and moral efficacy. From above four models, it can be seen that, in model $1, \beta=0.244$ $(\mathrm{P}<0.001), \quad \Delta \mathrm{R} 2=0.089 \quad(\mathrm{p}<0.001)$, which supported hypothesis 2 that ethical leadership was positively impacting on ethical climate. In model $2, \beta=0.107(\mathrm{P}<0.05), \Delta \mathrm{R} 2=$ $0.010(\mathrm{p}<0.05)$, hypothesis 1 is supported, representing ethical leadership positively influence moral efficacy. In the model 3 , $\Delta \mathrm{R} 2=0.019(\mathrm{p}<0.001)$ and $\beta=0.079(\mathrm{P}<0.05)$ and $\beta=0.120$ $(\mathrm{P}<0.05)$ respectively, which also can be consistent with what we predicated of hypothesis 3 . All the hypotheses gain a statistical supported from data.

TABLE II. REGRESSION RESULTS FOR MEDIATION-ETHICAL CLIMATE

\begin{tabular}{|l|c|c|c|}
\hline \multirow{2}{*}{ IV DV } & Model 1 & Model 2 & Model 3 \\
\cline { 2 - 4 } & $\mathrm{EC}$ & $\mathrm{ME}$ & $\mathrm{ME}$ \\
\cline { 2 - 4 } & $\beta$ & $\beta$ & $\beta$ \\
\hline 1.gender & .012 & -.12 & -.12 \\
\hline 2.age & -.03 & -.02 & -.02 \\
\hline 3.tenure & .04 & -.02 & -.02 \\
\hline 4.EL & $.24^{* * *}$ & $.11^{*}$ & $.08^{*}$ \\
\hline 5.EC & & & $.12^{*}$ \\
\hline R2 & $.10^{* * *}$ & $.03^{*}$ & $.04 * * *$ \\
\hline
\end{tabular}

Note. $\mathrm{N}=331, * \mathrm{P}<0.05$ (two-tailed test), $* * \mathrm{P}<0.01$ (two-tailed test), $* * * \mathrm{P}<0.001$ (two-tailed test), $\mathrm{DV}=$ Dependent variable, IV=Independent Variable, EL=Ethical Leadership, $\mathrm{EC}=$ Ethical Climate, $\mathrm{ME}=$ Moral Efficacy.

\section{THEORETICAL AND MANAGERIAL IMPLICATION}

This research is one of the first to explore the complementary of ethical leadership by exploring the influence of ethical leadership on individuals' psychological outcome, which is greatly neglect by previous research. Ajzen (1991) that efficacy offers individual with a sense of perceived control over his/her behavior and ability to implement. This study provides a new insight into individual's psychological change by using ethical leadership as a motivator [2]. Second, ethical climate work as a filter, deliver the impact from ethical leadership to raise employees' efficacy to deal with unethical issues. Also, this study provides some practical implications for organization management. First, leader should set an ethical role model for subordinates to imitate as leader have powerful in making vital decision concerning employees' welfare, and also shaping employees' belief by tell them what behavior organization would appreciate. Second, for the sake of achieving better ethical efficacy, ethical climate is suggested to establish in organization, building rule and regulations regarding ethics can be an useful tool for strengthening employees' moral belief.

\section{Limitation AND FUtURE RESEARCH DiRECTIONS}

In the first, our data sample is restricted in Southeast China, the research finding may not be used to evaluate the Northwest China or to a more great domain. Further research can do comparison to found whether culture difference would lead to a differ result. In the second, the valid sample is only 331 and it cannot provide a strong test of causal relationship between ethical leadership and moral efficacy. Further studies are recommended to exert with a more large scale of sample and focus on a specific industry to conduct relevant studies. Last but not least, we only test individual's efficacy in solve unethical problems. In order to have a comprehensive understanding individual's psychological process, more psychological factors, like moral ownership, moral courage, are suggested be investigate in the future.

\section{REFERENCE}

[1] Ahlheim, M., \& Schneider, F. (2000). Allowing For Household Preferences In Emission Trading? A Contribution To The Climate Policy Debate.

[2] Ajzen, I. (1991). The theory of planned behavior. Organizational Behavior and Human Decision Processes, 50, 179-211.

[3] Arnaud, A., \& Schminke, M. (2012). The ethical climate and context of organizations: a comprehensive model. Organization Science, 23(6), 1767-1780.

[4] Bandura, A. (1991). Social cognitive theory of self-regulation. Organizational behavior and human decision processes, 50(2), 248-287.

[5] Bandura, A. (1997). Self-efficacy: The exercise of control. W. H. Freeman \& Company, NewYork.

[6] Bartels, K. K., Harrick, E., Martell, K., \& Strickland, D. (1998). The relationship between ethical climate and ethical problems within human resource management. Journal of Business Ethics, 17(7), 799-804.

[7] Brislin, R. W. (1980). Translation and content analysis of oral and written material. Handbook of cross-cultural psychology, 2(2), 349-444.

[8] Brown, M. E., Treviño, L. K., \& Harrison, D. A. (2005). Ethical leadership: A social learning perspective for construct development and testing.Organizational behavior and human decision processes, 97(2), 117-134.

[9] Dickson, M. W., Smith, D. B., Grojean, M. W., \& Ehrhart, M. (2001). An organizational climate regarding ethics: The outcome of leader values and the practices that reflect them. The Leadership Quarterly, 12(2), 197-217.

[10] Gaertner, K. N. (1991). The effect of ethical climate on managers' decisions. Morality, rationality and efficiency: New perspectives on socio-economics, 211-223.

[11] Hannah, S. T., \& Avolio, B. J. (2010). Moral potency: building the capacity for character-based leadership. Consulting Psychology Journal Practice \& Research, 62(4), 291-310.

[12] Kozlowski, S. W., \& Doherty, M. L. (1989). Integration of climate and leadership: Examination of a neglected issue. Journal of applied psychology, 74(4), 546.

[13] Lu, C. S., Kuo, S. Y., \& Chiu, Y. T. (2013). Ethical leadership and ethical climate in the container shipping industry. International Journal of Shipping and Transport Logistics, 5(6), 591-604.

[14] Luria, G., \& Yagil, D. (2008). Procedural justice, ethical climate and service outcomes in restaurants. International Journal of Hospitality Management, 27(2), 276-283.

[15] Mayer, D. M., Kuenzi, M., \& Greenbaum, R. L. (2010). Examining the link between ethical leadership and employee misconduct: The mediating role of ethical climate. Journal of Business Ethics, 95(1), 7-16.

[16] Mayer, D. M., Kuenzi, M., Greenbaum, R., Bardes, M., \& Salvador, R. B. (2009). How low does ethical leadership flow? Test of a trickle-down model. Organizational Behavior and Human Decision Processes, 108(1), $1-13$.

[17] Salancik, G. R., \& Pfeffer, J. (1978). A social information processing approach to job attitudes and task design. Administrative science quarterly, 224-253.

[18] Schminke, M., Ambrose, M. L., \& Neubaum, D. O. (2005). The effect of leader moral development on ethical climate and employee attitudes. Organizational Behavior and Human Decision Processes, 97(2), $135-151$. 
[19] Schneider, B., \& Snyder, R. A. (1975). Some relationships between job satisfaction and organization climate. Journal of applied psychology, 60(3), 318.

[20] Schwepker, C. H. (2001). Ethical climate's relationship to job satisfaction, organizational commitment, and turnover intention in the sales force. Journal of Business Research, 54(1), 39-52.

[21] Victor, B., \& Cullen, J. B. (1988). The organizational bases of ethical work climates. Administrative science quarterly, 101-125.

[22] Walumbwa, F. O., \& Schaubroeck, J. (2009). Leader personality traits and employee voice behavior: mediating roles of ethical leadership and work group psychological safety. The Journal of Applied Psychology, 94(5), 1275-86.

[23] Walumbwa, F. O., Peterson, S. J., Avolio, B. J., \& Hartnell, C. A. (2010). An investigation of the relationships among leader and follower psychological capital, service climate, and job performance. Personnel Psychology, 63(4), 937-963.

[24] Zohar, D. (2005, April). Safety as a Marker of Corporate Ethics. In Nova Scotia Safety Council Conference. 